\title{
Social Costs of War Against Terrorism in Pakistan (2002-2012)
}

\section{Ishrat Afshan Abbasi ${ }^{1}$, Mukesh Kumar Khatwani ${ }^{2, *}$ and Farida Yasmin Panhwar ${ }^{3}$}

1Department of International Relations, University of Sindh, Jamshoro, Pakistan

${ }^{2}$ Area Study Centre, Far East \& Southeast Asia, University of Sindh, Jamshoro, Pakistan

${ }^{3}$ Institute of English Language and Literature, University of Sindh, Jamshoro, Pakistan

Article Type: Article

Article Citation: Ishrat Afshan Abbasi, Mukesh Kumar Khatwani, Farida Yasmin Panhwar. Social costs of war against terrorism in Pakistan (2002-2012). Indian Journal of Science and Technology. 2020; 13(02), 127-140. DOl: 10.17485/ijst/2020/ v013i02/146113

Received date: July 19, 2019

Accepted date: November 6, 2019

*Author for correspondence: Mukesh Kumar Khatwani mukesh. khatwani@usindh.edu.pk $\odot$ Area Study Centre, Far East and Southeast Asia, University of Sindh, Jamshoro, Pakistan

\begin{abstract}
Objective: The terrorist attacks of September 9/11 ensued war on terror, which had world-wide implications. Being a front-line state in this war, Pakistan faced several human security challenges and risks on social, economic, and psychological grounds. This article critically analyses the impact of war on terror, which jeopardized lives of common people and aggravated militancy and extremism in the country. Method: This is a qualitative case study research that tries to establish an in-depth understanding of the social phenomenon of war on terror and its consequences on the social setup of human life in Pakistan. Findings: The major finding of research reveals that the war on terror caused religious extremism, suicide bombing culture, external intervention, and internal displacement. Recommendations: In order to control terrorism in Pakistan and to mitigate the post-war on terror effects, this research recommends to develop and enhance coordination in the affairs of main functionary bodies of the country like government, security forces, and intelligence agencies.
\end{abstract}

Keywords: Extremism, Terrorism, Islamization, Suicide Bombing, Drone Attacks.

\section{Introduction}

The phrase "war against terrorism" was first introduced by the former US President George W. Bush and it was frequently popularized by eminent US bureaucrats, administrators, representatives, and spokespersons. The campaign went under way by 2001 following the terrorist attacks on the World Trade Center and Pentagon on 11 September 2001 [1]. The campaign was launched with the US/UK invasion of Afghanistan proclaiming a struggle against the terrorist organizations and alleging them for having connections 
to those organizations supposedly posing a threat to the US and its allies in particular. The particular focus of the designated campaign was Islamist militants and al-Qaeda. Pakistan's geographical proximity to Afghanistan made it a front-line state in the US-led invasion of Afghanistan. Pakistan provided it has all out support to the coalition forces against the Taliban regime [2].

This US attack caused a huge displacement in Afghanistan and compelled the people to take refuge in the religiously, ethnically, and culturally associated tribal areas of Pakistan. This displacement also provided a safe passage to some Taliban and al-Qaeda remnants to northern areas of Pakistan. This cross border displacement of people from Afghanistan to Pakistan caused social, political, and economic destabilization in Pakistan. Pakistan's role as a front-line state in the "War on Terror" has had profound implications for its domestic politics and foreign policy. The main significant steps, Pakistan took on urgency, were a U-turn on its Afghanistan policy, to carry out military operations against the terrorist factions in tribal areas and the adjacent localities of North West Frontier Province (NWFP) then. Despite Pakistani government and military's claims of resounding success against terrorist bodies in the former strong holds such as Swat, Malakand, Kurram Agency, Kohat, Orakzai, Bannu and large parts of South Waziristan the questions remain unanswered as to the alleviation of extremist, and terrorist activities within frontiers [3].

Contrary to the claims, the frequency, and intensity of Tehrik-e-Taliban Pakistan's (TTP) activities intensified not only in NWFP but also in the densely populated areas of the country. These gestures reinforce that TTP will engage security forces and the government in a new urban warfare scenario where they hold the advantage of being firmly entrenched within the country's major cities. Pakistan is the most affected state as a global war on terrorism; she has sacrificed lives (both civilian and military), material, and the infrastructure. Governance system has been badly disturbed due to the involvement of civil government in military forces in counter terrorism role [4].

The cost of the operations has been exceptional in terms of threat to human security both monetarily, and in terms of loss of lives. With regard to threat to human security, this article analyses the core social costs of war on terror in Pakistan. These social costs include the following: (i) Rise in militancy and extremism, (ii) Controversial drone attacks, (iii) Increasing suicide attacks, and (iv) Internally displaced persons (IDPs).

\section{Research Methodology}

This is a qualitative research, which focuses on "what and why" questions for the deep understanding of social implications and costs of the US-led war on terror. This research uses case study and historical analysis of war on terror. This research is a context-dependent as it carefully reports a certain time period with reference to particular situations emerged after 9/11 events when the war against terrorism started in Pakistan. Thereby, it interprets the whole phenomenon thematically. Since this subject "costs of war on terror" is too complex, therefore, qualitative analysis of a case study is more practicable to analyze this subject deeply and it also helps ingenerating useful data about the concerned phenomenon $[5]$. 
Since this is a historical research, therefore, it interprets and analyzes the data from secondary source material such as books, articles, e-publications, encyclopedias, and annual reviews and reports by various organizations/institutes. The secondary sources are very crucial in social research that focuses on a specific phenomenon in a particular geographical region along with a time-bound. The importance of secondary data is equal to those of primary data as Natalie L. Sproull writes "The secondary sources are not necessarily worse than primary sources and can be equally valuable" [6]. Furthermore, keeping in mind the time and cost analysis, we preferred to collect secondary sources instead of primary. This approach proved to be less-costly and time consuming than primary data collection method.

\section{Findings and Discussions}

\subsection{Rise in Militancy and Extremism}

When the government of Pakistan participated in the US-led war on terrorism; it went against its old policy to support religious groups. To understand the rise in militancy and extremism in Pakistan, it is essential to review history of different regimes in Pakistan.

Field Marshal Ayub Khan preferred to control and regularize Madrasahs operated by religious organizations and introduced the idea of moderate Islam. His ideology aimed at legitimizing his military power, strengthening the position of Pakistan on international level against India and revitalizing alignment with the US. In order to implement the new version of Islam (moderate Islam), Ayub government introduced Auqaaf system, and tried to reform Madrasah by granting them the equivalence of public sector certificates and diplomas. His policy failed because all major parties except Jamaat-i-Islami rejected his policy.

As a result, a number of new madrasahs were opened with the literary and monetary assistance of Saudi Arabia [7]. During Zulfiqar Ali Bhutto era, a nexus originated between madrasahs and military. It was time when Afghan leaders Gulbuddin Hekmatyar, Burhannudin Rabbani, and Ahmad Shah Massoud took refuge in Pakistan. Pakistan offered them assistance and sanctuaries to contain communism and USSR's imperialist policies in Afghanistan. These leaders were accompanied by religious teachers who introduced militant teaching in madrasahs of Pakistan against Soviet Union [8].

Contemporary Islamic militancy in Pakistan traces back to General Zia-ul-Haq's rule (1977-1988) when he came into power through military coup. Under his policy of Islamization of Pakistan, General Zia ul Haq rewarded religious parties offering them high ranked designations in government and win their support for waging war in Afghanistan against communist USSR. Thus, General Zia ul Haq's policy of Islamization and Afghan jihad rooted seed of fundamentalism in Pakistan. Madrasahs turned into school of militancy and jihadi education [9].

It is alleged that the Pakistani military, especially the Inter-Services Intelligence Directorate (ISI), trained Jihadis at camps established in the tribal areas against communism with the financial aid by Saudi Arabia and the United States of America. These madrasahs 
did not necessarily conduct military training or provide arms to students but encouraged them to join the Mujahideen inside Afghanistan.

In the early 1980s, special text books on jihadi values were published in Dari and Pashtu languages with the assistance of USAID and Centre for Afghanistan Studies at the University of Nebraska-Omaha. This literature intensified extremist elements because it was not destroyed after war and it is still used by Taliban and other like-minded non-state actors.

When General Musharraf took power through a military coup in October 1999, his main policy towards these madrasahs was categorically different from previous military as well as civilian governments' policies. He intended to stop exploitation of religion and extremism in Pakistan. After September 9/11, the US pressure and UN Security Council's resolution 1373 put him under pressure for the decisive action against extremist forces in Pakistan. It was a challenge to crack down on madrasahs and religious groups since the government, military and intelligence agencies were unwilling for the eradication of these religious groups under consideration of their Kashmir policy and very old roots of the madrasahs.

Initially, Musharraf took action against the active madrasahs and religious organizations in Pakistan and Kashmir. Many activists were arrested and madrasahs were closed in NWFP.

However, despite international pressures and visible actions, extremism and militancy kept on increasing in Pakistan. It was alleged that Pakistani paramilitary and police did not resist the volunteers crossing borders to fight alongside Taliban in Afghanistan. One of its examples was the leader of Tehreek-e-Nafaz-e-Shariat-e-Mohammadi (TNSM), Sufi Mohammad who crossed border in October 2002 with 10,000 volunteers. In addition, those Jihadis, who were arrested temporarily, were not imprisoned with serious criminal charges [10].

Counter terrorist operations launched by Pakistani government and armed forces and the drone strikes by the US against the militants had serious blow back effects on the insurgency. All these counter terrorism actions led to the critical escalation of terrorist activities in Pakistan. Militants intensified their actions in terms of number of suicide attacks, target killings and civilian causalities. Militant groups with a variety of different backgrounds and affiliations such as al Qaeda, Pakistani Taliban, and other local and foreign Islamic militants groups created a close coordination and cooperation in their operations. These militant groups possessed more sophisticated weapons and extended the circle of their movements and violent actions beyond the mountainous territories of FATA [11]. Following their intense plans, they turned the major cities of Punjab, Baluchistan, and Sindh as a part of their new battlefield. As a result, suicide bombing, target killings took place in the urban centers and army headquarters in the major cities including Rawalpindi, Multan, Faisalabad, Lahore, Quetta, and Karachi in order to carry on their new strategy smoothly.

Furthermore, drone strikes and military operations significantly increased the number of militant recruits. Militants instigated family members of the victims against the government and army of Pakistan as well as the United States. They facilitated victims to join the militants' group and trained them mentally and physically for becoming the target killer and suicide bomber. This recruitment was not confined to the illiterate 
class of victimized area, the well-educated youth of the victimized families or those who had closely observed the volatile condition of the areas and the consequences of the barbarian strikes and operation also joined those militant groups. As stated by Baitullah Mehsud "each drone attack brought him three or four more suicide bombers" [12]. Thus, militants challenged the government's writ quite several times through targeting political personalities, army personnel, and international organizations. In April 2007, then interior minister of Pakistan Aftab Ahmed Khan Sherpao was attacked in a political crowd at his own home town Charsada, in the NWFP, and twenty-eight innocent people lost their lives.

The high-profile attacks occurred respectively on 18 October 2007 and 27 December 2007 against Pakistan's high-profile personality Ms. Benazir Bhutto. On 18 October 2007 when Ms. Bhutto returned to Pakistan, her welcome procession was attacked, the target figure was Ms. Bhutto herself. Two massive blasts hit her truck, she survived the attack, but more than 140 people including her security guards and policemen lost their lives in this suicide attack [13]. Ms. Bhutto was on the target list of al-Qaeda and she was threatened by al-Qaeda for supporting US in its policies against al-Qaeda. She always accused ISI and retired military officials for her assassination plans and accused al-Qaeda and Taliban as the operators or pawns of this plan.

After addressing an election rally at Liaqauat Bagh, Rawalpindi she was leaving the garden in her bullet-proof sport utility vehicle, and while waving a hand to her supporters, she got a pistol shot on her head followed by a massive explosion. Ms. Benazir shot dead on the spot and many other supporters also lost their lives as a result of suicide attack. Government accused TTP for the assassination of Ms. Bhutto and as proof released an intercepted greeting message between Baitullah and his supporter on the death of her killing taking credit of the assassination.

In the succeeding months, Taliban movement brushed away the whole north western region of Pakistan, and stretched to the Bajur and Mohmand tribal regions, which border the Khyber Pakhtunkhwa (KPK), formerly known as North-West Frontier Province. Afterward the attacks led to urban centres of Pakistan among them the most disastrous were 10 October 2009 attack on General Headquarters in Rawalpindi. The attack led to the deaths of nine militants and two civilians and one wounded militant was arrested by security forces. The militants not only attacked the headquarters, but they hostage civilian and military officials who were released through rescue operation under the code name of Operation Janbaz [14]. In 2009, twin suicide attacks occurred at the International Islamic University, Islamabad [15]. On 9 July 2010, a suicide bomb attack in Yakaghund market, Mohmand Agency, and FAT. A targeted tribal elders' meeting (known as Jirga in the local cultural context). According to news report around 104 people was killed and more than 120 were wounded [15-16]. The attack was reaction of TTP against government's military campaign in Mohmand Agency in the late 2009 and early 2010. On 6 December 2010, two suicide bombers camouflaged in police uniform targeted Ghalanai the main city of Mohmand Agency in FATA. The main target of the attacks was Jirga convened by government officials, tribal elders and some other groups to make a fresh plan against Taliban. The attacks took life of 50 people and more than 100 people were wounded [17].

TTP claimed the responsibility for the attacks. On 22 May 2011, TTP attacked Pakistan Naval Station (PNS) Mehran, the headquarter of the Pakistan Navy's Naval Air Arm, 
located at the PAF's Faisal Force Base of Karachi and destroyed the air craft and other surveillance air craft [18]. Subsequently, the militants also went into the close buildings and opened fire on naval personnel. Prior to this attack, the Pakistan Navy was twice targeted first on 21 April 2011 when two naval buses were attacked and then again on 28 April 2011 on a Naval coaster and had caused of 12 killings. Soon after the attack was countered by Special Service Group-Navy, SSG (N). Having cordoned off the building the team warned the militants to surrender and entered the building to search the rest of the attackers [19].

Apart from above mentioned incidents of increasing extremism, the details of reported casualties (civilian, security forces, and terrorists) are presented in the following Table 1.

\subsection{The Drone Strikes}

The US-led drone strikes guided Pakistani forces in their ground operations by identifying the main targets and militants' positions. These drone strikes provoked the Pakistani public and instigated controversy on public level as a clash between state and public against the US. These strikes were never officially acknowledged by US until it came into public knowledge itself on 1 January 2003 when a drone crashed soon after taking off. Islamabad always denied any such US intervention in Pakistan for years. However, it is inconceivable that government of Pakistan was unaware of this US action. Further incidents disclosed that these drone operations were carried out with the consent and knowledge of government of Pakistan.

According to the leadership of TTP, each single drone strike caused an increase in the number of militant recruits because families of victims demanded revenge of the causalities, which instigated them to join TTP. Since Pakistan was not officially at war; therefore, usage of drone attacks was a breach of international law and violation of UN declaration of Human Rights. Attacks were highly questionable and in principal both US and Pakistan were involved respectively in War Terrorism and State Terrorism [20].

TABLE 1. Fatalities in terrorist violence in Pakistan (2003-2012)

\begin{tabular}{lcccr}
\hline Year & Civilians & Security personnel & Terrorists/lnsurgents & Total \\
\hline 2003 & 140 & 24 & 25 & 189 \\
2004 & 435 & 184 & 244 & 863 \\
2005 & 430 & 81 & 137 & 648 \\
2006 & 608 & 325 & 538 & 1471 \\
2007 & 1522 & 597 & 1479 & 3598 \\
2008 & 2155 & 654 & 3906 & 6715 \\
2009 & 2324 & 991 & 8389 & 11704 \\
2010 & 1796 & 469 & 5170 & 7435 \\
2011 & 2738 & 765 & 2800 & 6303 \\
2012 & 981 & 350 & 1094 & 2425 \\
Total & $\mathbf{1 3 1 2 9}$ & $\mathbf{4 4 4 0}$ & $\mathbf{2 3 7 8 2}$ & $\mathbf{4 1 3 5 1}$ \\
\hline
\end{tabular}

Data till 20 May 2012.

Source: http://www.satp.org/satporgtp/countries/pakistan/database/casualties.htm 
The reason of Pakistan's secret cooperation with US operations was to get assistance to eradicate al-Qaida remnants from Pakistan. In this regard, the killing of some leading figures of al-Qaida is notable; such as killing of Nek Muhammad (TTP Chief) on 17 June 2004; killing of Abu Hamza Rabia in December 2005, who was also allegedly involved in assassination attempts on General Pervaiz Musharrafkilling of a top Al-Qaida leader, Abu Liath Al Libbi on 29 January 2008, who was allegedly involved in an assassination attempt on US Vice President Dick Cheney.

It is reported that from 2007 to 2009 almost 12 top al-Qaida leaders along with 12 more low ranked figures were killed in these drone strikes. However, these strikes caused high human casualties [21].

The drone operations were first time widely condemned publicly in January 2006 when drone operations were taken beyond Waziristan in a village Damadola of Bajur district to search Aymen al-Zwahiri and other al-Qaida operatives. This attack caused several civilian causalities. Once again, Pakistan declined the role of CIA and owned the responsibility as a part of Pakistan military operations. The horrendous event was followed by the public protests and compelled government to accept the reality and condemned the attacks that caused civilian causalities.

US drone strikes in Pakistan raised several questions. For instance, why did US intervene in Pakistan and why did Pakistan give consent to US-intervention? Actually, US always showed trust deficit in government of Pakistan and Pakistani intelligence agencies for poor strategy against terrorist and leak out of the secret plans. The US was always suspicious of dual policies of Pakistan on 'War on Terror'. By this reason, Bush passed a secret order for authorizing CIA for carrying out assaults inside Pakistan against al-Qaeda operatives [22]. Despite the fact that US lacked trust on Pakistan, it was believed that administration of Pakistan had given its consent to the CIA based drone operation for the success of its self-launching operations.

According to the Brooking Institution, single drone strike against a single militant might kill 10 civilians. This US intervention and infringement of Pakistan's sovereignty, and the civilian deaths as a result of the drone attacks caused increasing extremism and intensifying suicide attacks [23]. The secret deal between Pakistan and US regarding drone attacks was reported on 4 October 2008 by Washington Post. This news was rejected by the then Foreign Minister of Pakistan. In response to such statements/reports, Pakistan requested US to give them control over drones and provide them required technical training and assistance but US rejected for the fear of leakage of the intelligence information about militant targets [24]. Causalities in Drone Attacks (2005-2012) are provided in Table 2.

\subsection{Suicide Bombing Culture}

Suicide bombing culture is such a terrorist practice in which military as well as civilian sites are targeted. In this attack, the attacker intends to target some important sites or personalities, and knows that big number of common people will certainly die in the process. The means of attack include vehicles filled with explosives, passenger planes carrying large amounts of fuel, and individuals wearing vests filled with explosives [25]. 
TABLE 2. Causalities in drone attacks (2005-2012)

\begin{tabular}{cccc}
\hline Year & Incidents & Killed & Injured \\
\hline 2005 & 1 & 1 & 0 \\
2006 & 0 & 0 & 0 \\
2007 & 1 & 20 & 15 \\
2008 & 19 & 156 & 17 \\
2009 & 46 & 536 & 75 \\
2010 & 90 & 831 & 85 \\
2011 & 59 & 548 & 52 \\
2012 & 14 & 101 & 7 \\
Total & $\mathbf{2 3 0}$ & $\mathbf{2 1 9 3}$ & $\mathbf{2 5 1}$ \\
\hline
\end{tabular}

Data till May 2012.

Source: http://www.satp.org/satporgtp/countries/pakistan/database/ Droneattack.htm

Pakistan is witnessing this culture since 1980s when the emergence of militant Islam in the form of madrasahs started teaching militancy against USSR. Since 9/11 attacks suicide bombing has been weapon of all extremist groups to resist the government's actions against them and impose heavy causalities on government. The quantity and quality of suicide attacks have increased since 2001 when Pakistan participated the US-led war against terrorism are presented in Table 3.

Taking into account the post 9/11 era, we can notice that initial targets of these attacks were security forces and governmental institutions. Over the time, as the government intensified its attempts against terrorists the number of suicide attacks got increased every year as a reaction. During 2001 to 2012, suicide attacks became a common practice of militants in Pakistan. Public spots such as shopping malls, place of worship, processions, and academic institutions were targeted.

Here the question arises what drives the suicide bomber to be tool of this game of extremism? Research reveals there are several tangible and intangible factors. According to some analysts, the most important reasons are as following:

(i) False faith and commitment with religion

(ii) Sense of feeling for the miseries and plight of Muslim brethren at the hands of Western powers and their allies.

(iii) Sense of desperation and weakness to fight one-on-one with superior authorities [26].

TABLE 3. Suicide attacks since 2001

\begin{tabular}{lccc}
\hline Year & $\begin{array}{c}\text { No. of } \\
\text { attacks }\end{array}$ & $\begin{array}{c}\text { No. of } \\
\text { killings }\end{array}$ & $\begin{array}{c}\text { No. of } \\
\text { injuries }\end{array}$ \\
\hline $2001-2008$ & 130 & 1883 & 3819 \\
2009 & 86 & 1217 & 2305 \\
2010 & 52 & 1224 & 2157 \\
2011 & 12 & 82 & 341 \\
Total & $\mathbf{2 8 0}$ & $\mathbf{4 3 2 4}$ & $\mathbf{8 6 2 2}$ \\
\hline
\end{tabular}

Source: www.insider.pk/national/politics/

analysis-of-suicide-bombings-in-pakistan/ 
Among the suicide bombers, the number of young boys between the age of twelve and eighteen is reported higher than elders. There are several reasons for the involvement of teenagers in suicide bombing. First, these students belong to madaras. The primary reason for parents to send their children to madrassas as opposed to mainstream schools was that these institutions provided a good Islamic education and provided education on low cost along with the provision of food and clothing [27].

Firstly, foremost young children are comparatively less suspicious than elders so they can easily reach anywhere unnoticed. They are more emotional so they can be easily brainwashed in terms of creed and belief. They can be easily provoked for taking the revenge of their causalities and killing of their siblings during operations and drone strikes as it was claimed by TTP chief Baitullah Mehsud during a meeting with journalists and trainer of suicide bombers Qari Hussain commander of TTP. Besides, some poverty stricken youngsters also prefer to join such mission for getting rid of the hardships of life with easy bargaining for heaven. Moreover, poor parents send their children to radical madrasahs where they get free education and free food from extremist mullahs who wash their brains in favour of their own sectarian and fundamentalist creed and turn them into jihadi fighters. These youngsters are easily taken away from these madrasahs without knowledge and consent of their parents and sent on suicide missions. During the training days, these boys are kept away from all others social activities, friends and relatives and provided religious literature to learn the dignity of martyrs.

\section{Internally Displaced Persons (IDPs)}

The military operations in FATA had caused millions of peoples' displacement. The main affected areas of displacement were Buner, Dir, Swat, and South Waziristan where people were already suffering from scarcity of food and medicine and life threats from Taliban.

In [28] fact, internal displacement started by the year of 2004 but a huge scale internal displacement was witnessed from 2008 to 2010. According to official reports around two million people were displaced among them 1.4 were registered. In the early years, the causes of displacement were tribal and sectarian clashes but the massive scale displacement started by 2007 due to military operations in FATA. In 2007, the first military operation in North Waziristan had been cause of the displacement of 80,000 people. Operation Zalzala in January 2008 at South Waziristan caused 200,000 displacement, the migrants lived for the time being in Dera Ismail Khan and Tanks. In the same year, again 35,000 people were displaced as a result of Operation SherDil in Bajur Agency. Moreover, around 200,000300,000 people were displaced from Mohmand Agency, almost 100,000 people were displaced from Khyber agency as a result of series of military operations and migrated to Peshawar and nearby areas. From Orakzai agency About 100,000 to 200,000 people were displaced from Orakzai Agency to Hangu and Kohat [29].

Due to influx displacement, a number of camps were established in Peshawar, Lower Dir, Dera Ismail Khan, Tank and inside Mohmand Agency. Nevertheless, many people preferred to live out of the camps with relatives or families because of "pardah"-Pardah, meaning curtain or veiling, is commonly used for regulating female modesty in Muslim 
societies [30]. In these camps along with government organizations, NGOs also tried to play their role to facilitate IDP seven so they could not access to all people properly because of their own less resources. However, according to official figures, the number of IDPs was 1.4 million nonetheless Internal Displacement Monitoring Center (IDMC) estimates that this number was 1,470,000-2,000,000 in July 2010. On the other hand, World Health Organization (WHO) reported that the total number of IDPs had been 1,968,000 in April 2010. The reason of increase in number was unregistered people who were $25-50 \%$ higher than the official Figure 1 [31].

First time in 2009 after the flow of IDPs from FATA and PATA, the government started registration process with the help of the United Nations High Commission for Refugees (UNHCR) and Social Welfare Department (SWD) and Commissioner for Afghan Refugees (CAR) and NADRA - a federal body for issuing National Identity Cards to Pakistani citizens. Despite conducting this process, some IDPs could not be registered for some problems and difficulties such as:

Having no computerized CNIC particularly of women

Insufficient Infra-structure and registration sites

Scarce information about the registration process

Lack of separate counter for women

Threats to public officials

Suicide attacks at campus for instance at Kacha Pakha camp in Kohat provoked closure of camps.

Accommodating for the IDPs was a big issue due to security problems and seclusion for women, therefore, more than $85 \%$ of the IDPs in KPK reported to live in schools, mosques, and private homes or with relatives [32]. Government provided cash cards to IDPs for food and medical care, while those who were living privately had to depend on their own income because there was food scarcity [33]. Despite the availability of camps, there was a lack of funding for the people from international agencies owing to insecurity and refusal or direct access to displaced persons. According to the Asian Development Bank Report

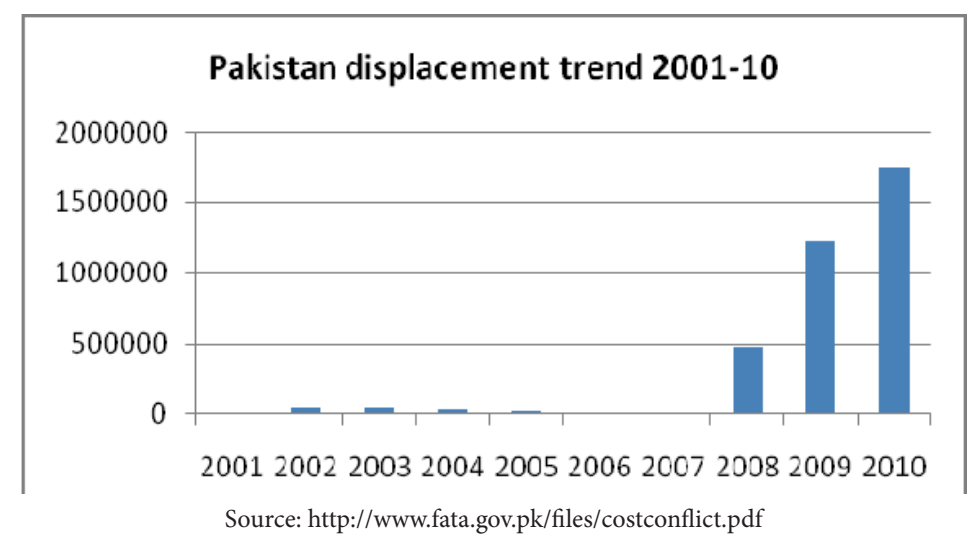

FIGURE 1. IDPs trends in Pakistan (2001-2010). 
about Post-Conflict Needs Assessment the damage to health facilities was caused by being deficient in right to use of clean water, scarcity of nutrition, insecurity and wounds during fighting [34].

During displacement women, elderly men and children were exposed to vulnerability. Women had been intensely disturbed due to insecure situation such as sexual harassment and other forced actions. Similarly, men were also not exempted of the vulnerabilities; they were victim of assassination and injuries, forced recruitment in militant groups who had access to IDP scamps. Internally displaced children were exposed to diseases, kidnapping, sexual exploitation, and other violence. Internally displaced persons' life was also at risk because of expected suicide bombing attack on camps are shown in Figure 2 [35].

The migration created two problems on provincial level the first one was opposition against influx of IDPs and the second one was Dilemma of Identity. IDPs' influx was opposed at provincial level in Sindh where nationalist parties protested against the heavy influx of IDPs in Karachi.

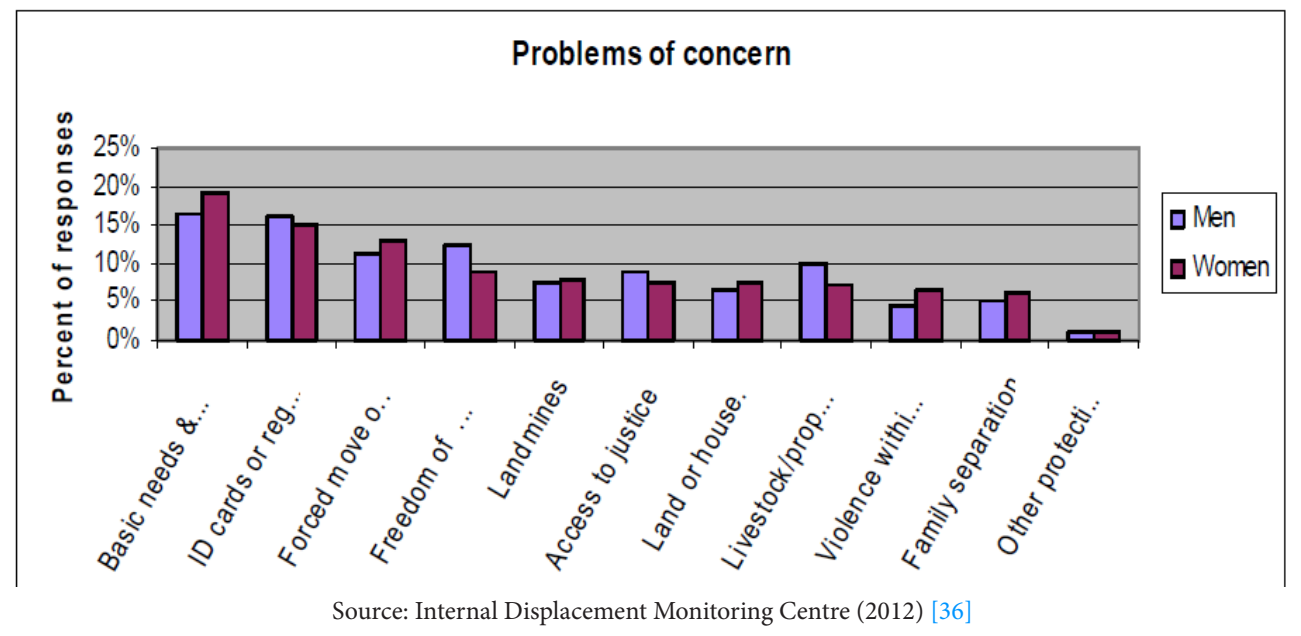

FIGURE 2. Problems faced by IDPs in camps.

The second reason was native population's fears that their economic resources, economic opportunities would be clutched by the migratory. Thereby, internal displacement furthered the inter-provincial conflict in Pakistan.

In Punjab, it was assumed that if a large number of people from NWFP stays in Punjab, they would create a large group of Pashtu minority there; therefore, the locals were concerned about the ethnic balance in the province. In view of Punjab's concerns, camps were established by the main roads in Sindh and IDPs were forced to register in order to enable the security forces to control the population. Another most significant problem linked with the displacement of the people was the identity crisis. As the people of different cultures and traditions were entering other provinces, the locals assumed it a threat to their culture and identity. 


\section{Conclusion}

This research explores that in Pakistan, proliferation of Jihadi organizations was the result of the theological predominance in the form of thousands of radical madrasahs; these madrasahs were involved in spreading religious extremism, sectarianism. The owners of theses madrasahs plus the preachers' mission were mingled with political interests. For the achievement of their interest and promotion of their ideologies they started to recruit young and educated boys. The expected benefit might be in the form of financial rewards, or elevated status within the terrorist organization or seizure of state's power, religious service or even promise for martyr's paradise.

After withdrawal of Soviet Russia, when the government was devising a corrective strategy for Afghanistan, the Taliban seized power in Afghanistan which gave an opportunity to Al-Qaida and other religious groups to reassert themselves making Afghanistan as hub of their activities especially against USA and other western countries, the consequence was 9/11 attacks. After 9/11 once again Pakistan was compelled to jump into war. Along with economic setbacks Pakistan faced several devastating, social, political and psychological consequences of this war. In this blind campaign well known personalities like Benazir Bhutto, Molana Attaullah Jan, Molana Sarfaraz Naemi, Member of the provincial Assembly NWFP Aalamzad Khan, General Mustaque Baig, 100s of Pakistani soldiers, and 1000s of Pakistani innocent civilians lost their lives in suicide and drone attacks. The whole Pakistan was put under strong high alert due to huge influx of displacement.

\section{References}

1. Bush and cabinet tell us. https://www.nydailynews.com/archives/news/fight-evil-bush-cabinetu-s-article-1.919650. Date accessed: 2001.

2. The Osama Bin Laden I know: an oral history of Al-Qaeda's leader. https://www.amazon.com/ Osama-bin-Laden-Know-History/dp/0743278925. Date accessed: 08/08/2006.

3. Shah MA. Pakistan's foreign policy analysis. Pakistan Horizon. 2007; 2(60), 85-107.

4. Khalid M, Akhter F. Terrorism in Pakistan: genesis, damages and way forward. Journal of Management Sciences. 2019; 6(1), 105-114.

5. Introduction: the discipline and practice of qualitative research. https://psycnet.apa.org/ record/2005-07735-001. Date accessed: 2005.

6. Handbook of research methods: a guide for practitioners and students in the social sciences. https://www.amazon.com/Handbook-Research-Methods-Practitioners-Students/dp/ 0810844869. Date accessed: 03/2003.

7. Sultana R. A study of Talibanization in Pakistan. Journal of History and Culture. 2008; 2(29), 119-136.

8. Javed, U. Genesis and effects of religious extremism in Pakistan. International Journal of Business and Social Science. 2011; 7(2), 282-288.

9. Ibid. https://en.wikipedia.org/wiki/Ibid. Date accessed: 04/09/2019.

10. Pakistan: Madrassahsas, extremism and the military. https://www.crisisgroup.org/asia/southasia/pakistan/pakistan-madrasas-extremism-and-military. Date accessed: 2002.

11. Abbasi IA. Pakistan's participation in the war on terror and US concerns: an analysis. JISR: Management, Social Sciences \& Economics. 2013; 1(11), 99-106. 
12. The scorpion's tail. https://en.wikipedia.org/wiki/Sting_in_the_Tail. Date accessed: 25/09/2019.

13. Ibid P-137. https://shodhganga.inflibnet.ac.in/bitstream/10603/59407/11/11_references.pdf. Date accessed: 2016.

14. Pakistan army raid frees hostages. http://news.bbc.co.uk/2/hi/south_asia/8301175.stm. Date accessed: 2009.

15. Two explosions hit Islamabad university hostages. https://www.theguardian.com/world/2009/ oct/20/islamabad-university-explosions. Date accessed: 2009.

16. Suicide attacks in Mohmand kill 104; peace Jirga main target. https://www.dawn.com/ news/858504. Date accessed: 10/07/2010.

17. Suicide attack in Pakistan tribal village kills dozens. https://www.bbc.com/news/10566358. Date accessed: 09/07/2010.

18. Pakistan's Kashmir policy and strategy since 1947. https://calhoun.nps.edu/handle/10945/1627. Date accessed: 2004.

19. PNS Mehran attack was a big security lapse. https://www.thenews.com.pk/archive/print/303250experts-say-pns-mehran-attack-was-a-big-security-lapse. Date accessed: 12/06/2019.

20. Scorpion's tail. https://www.noahsarkwaterpark.com/attractions/scorpions-tail. Date accessed: 2019.

21. Ibid. 80-81. http://reference.bahai.org/en/t/ab/PT/pt-26.html. Date accessed: 17972.

22. .Ibid 145-146. https://indiankanoon.org/search/?formInput=crpc\%20sec\%20145\%2C\%20146. Date accessed: 2019.

23. Do target killings work? Brookings. https://www.brookings.edu/opinions/do-targeted-killingswork-2/. Date accessed: 14/07/2009.

24. Shams-ur-Rehman GA. Critical study of the legal position of the US drone strikes in the FATA. Pakistan Journal of Social Sciences. 2014; 1(34), 101-110.

25. Suicide bomber: phenomenon, strategy and future. Summit Enterprises: New Delhi. http:// www.octanegames.com.au/suicide_bomber_phenomenon_strategy_and_future.pdf. Date accessed: 2008.

26. Cost of war on terror for Pakistan economy. Ministry of Finance and Economic Affairs Secretariat. Government of Pakistan, 2012 May 15.

27. Nizami AT, Hassan TM, Yasir S, Rana MH, Minhas FA. Terrorism in Pakistan: the psychosocial context and why it matters. BJPsych International. 2018; 15(1), 20-22.

28. Khatwani, M.K. Professional women's perceptions \& experiences of respectability, social status, and autonomy: a case study of women employed at the University of Sindh, Jamshoro, SindhPakistan. http://sro.sussex.ac.uk/id/eprint/65819. Date accessed: 2016.

29. Pakistan: flooding worsens situation for people displaced by conflict in North-West. http:// www.internal-displacement.org/publications/pakistan-flooding-worsens-situation-for-peopledisplaced-by-conflict-in-north-west. Date accessed: 2010.

30. Pakistan's IDP crisis: challenges and opportunities. International Crisis Group. http://www. internal-displacement.org/8025708F004CE90B/(httpDocuments)/76943CB4EF4EC684C1257 6550055BE7C/\$file/ICG-+3+June+2009+Pakistan's+IDP+Crisis+Challenges+and+Opportuni ties.pdf. Date accessed: 03/06/2009.

31. Baseline survey of national program for food security and agricultural productivity enhancement in Pakistan. http://home.wfp.org/stellent/groups/public/documents/ena/wfp 201134.pdf. Date accessed: 2008.

32. North-West frontier province and federally administered tribal areas: preliminary damage and needs assessment - immediate restoration and medium term reconstruction in crisis affected 
areas. http://www.adb.org/Documents/Reports/PAK-FATA-Damage-Needs-Assesment-Nov2009.pdf. Date accessed: 2009.

33. Last in line for food. http://www.irinnews.org/report.aspx?ReportId=88685. Date accessed: 05/04/2010.

34. IDPs: challenge for Pakistan. http://www.cssforum.com.pk/css-compulsory-subjects/currentaffairs/25042-idps-challenge-pakistan.html. Date accessed: 2009.

35. Two-tier treatment in Pakistan's Jalozai camp. http://www.dawn.com/wps/wcm/connect/dawncontent-library/dawn/news/pakistan/provinces/04-two-tier-treatment-in-pakistan-jalozaicamp-qs-08. Date accessed: 19/06/2009.

36. Holding Pakistan, the second phase of Pakistan's counterinsurgency operation. http://www. foreignaffairs.com/articles/66176/holding-pakistan. Date accessed: 24/03/2010. 